\title{
Assessing the effect of pyrolysis temperature on the molecular properties and copper sorption capacity of a halophyte biochar ${ }^{\text {is }}$
}

\author{
Jing Wei ${ }^{a}$, Chen $\mathrm{Tu}^{\mathrm{a}}$, Guodong Yuan ${ }^{\mathrm{b},}{ }^{*}$, Ying Liu ${ }^{\mathrm{a}}$, Dongxue Bi ${ }^{\mathrm{a}}$, Liang Xiao ${ }^{\mathrm{a}}$, Jian Lu ${ }^{\mathrm{a}}$, \\ Benny K.G. Theng ${ }^{\mathrm{c}}$, Hailong Wang ${ }^{\mathrm{d}}$, Lijuan Zhang ${ }^{\mathrm{e}}$, Xiangzhi Zhang ${ }^{\mathrm{e}}$ \\ ${ }^{a}$ CAS Key Laboratory of Coastal Environmental Processes and Ecological Remediation, Yantai Institute of Coastal Zone Research, Chinese Academy of \\ Sciences (CAS), Yantai, 264003, China \\ b School of Environmental and Chemical Engineering, Zhaoqing University, Zhaoqing, 526061, China \\ ${ }^{c}$ Manaaki Whenua-Landcare Research, Private Bag 11052, Palmerston North, 4442, New Zealand \\ ${ }^{\mathrm{d}}$ School of Environment and Chemical Engineering, Foshan University, Foshan, 528000, China \\ e Shanghai Synchrotron Radiation Facility, Shanghai Advanced Research Institute, Chinese Academy of Sciences, Shanghai, 201204, China
}

\section{A R T I C L E I N F O}

\section{Article history:}

Received 30 October 2018

Received in revised form

9 April 2019

Accepted 28 April 2019

Available online 29 April 2019

\section{Keywords:}

Halophyte biochar

Copper

Pyrolysis temperature

Functional groups

Sorption mechanism

\begin{abstract}
A B S T R A C T
The capacity of biochar to take up heavy metals from contaminated soil and water is influenced by the pyrolysis temperature. We have prepared three biochar samples from Jerusalem artichoke stalks (JAS) by pyrolysis at 300,500 and $700{ }^{\circ} \mathrm{C}$, denoted as JAS300, JAS500, and JAS700, respectively. A variety of synchrotron-based techniques were used to assess the effect of pyrolysis temperature on the molecular properties and copper $(\mathrm{Cu})$ sorption capacity of the samples. The content of oxygen-containing functional groups in the biochar samples decreased, while that of aromatic structures and alkaline mineral components increased, with a rise in pyrolysis temperature. Scanning transmission X-ray microscopy indicated that sorbed $\mathrm{Cu}(\mathrm{II})$ was partially reduced to $\mathrm{Cu}(\mathrm{I})$, but this process was more evident with JAS300 and JAS700 than with JAS500. Carbon K-edge X-ray absorption near edge structure spectroscopy indicated that $\mathrm{Cu}(\mathrm{II})$ cations were sorbed to biochar via complexation and $\mathrm{Cu}-\pi$ bonding. With rising pyrolysis temperature, $\mathrm{Cu}(\mathrm{II})$-complexation weakened while $\mathrm{Cu}-\pi$ bonding was enhanced. In addition, the relatively high ash content and pH of JAS500 and JAS700 facilitated Cu precipitation and the formation of langite on the surface of biochar. The results of this investigation will aid the conversion of halophyte waste to useable biochar for the effective remediation of Cu-contaminated soil and water.
\end{abstract}

() 2019 Elsevier Ltd. All rights reserved.

\section{Introduction}

Biochar is a porous carbon-rich material produced by pyrolysis of biomass in a broad temperature range $\left(150-900^{\circ} \mathrm{C}\right)$ under limited oxygen conditions (Beesley et al., 2011; Godlewska et al., 2017). Besides being rich in aromatic structures and oxygencontaining functional groups, biochar also contains inorganic compounds such as carbonate and aluminosilicate minerals (Xu et al., 2017). As such, biochar has been widely used as a soil amendment to reduce greenhouse gas emission, improve soil fertility, and immobilize metal contaminants (Beesley et al., 2011;

\footnotetext{
ش This paper has been recommended for acceptance by Dr. Yong Sik Ok.

* Corresponding author.

E-mail address: yuanguodong@zqu.edu.cn (G. Yuan).
}

Godlewska et al., 2017; Rajapaksha et al., 2016). The physicochemical properties of biochar are closely linked to its pyrolysis temperature. For example, the porosity, $\mathrm{pH}$, and mineral contents of biochar increased with pyrolysis temperature (Ahmad et al., 2014; Li et al., 2017). Pyrolysis at high temperatures is conducive to feedstock (i.e. cellulose, hemicellulose, and lignin) conversion (Xu et al., 2017), decreasing oxygenated and unsaturated alkyl functional groups, and increasing aromatic structures (Awad et al., 2018), in the resultant biochar.

The above-mentioned changes in molecular properties affect the heavy metal sorption capacity of biochar but the data are not always self-consistent. Lead uptake by biochar derived from peanut shell and Chinese medicine residue by pyrolysis at $300-600{ }^{\circ} \mathrm{C}$, primarily occurred by precipitation, while $\mathrm{Pb}^{2+}$ complexation was reduced with a rise in pyrolysis temperature (Wang et al., 2015). On the other hand, Gao et al. (2019) found that feedstock type (rice 
straw, sewage sludge) was more important than pyrolysis temperature $\left(300,500\right.$, and $\left.700^{\circ} \mathrm{C}\right)$ in controlling the capacity and mechanism of $\mathrm{Cd}^{2+}$ sorption by biochar.

The choice of analytical techniques is equally important in elucidating the surface properties and heavy metal sorption mechanisms of biochar at the molecular level. In this regard, carbon K-edge X-ray absorption near edge structure spectroscopy (XANES) is a powerful technique for identifying and fingerprinting the fine structures of organic $\mathrm{C}$ in complex natural organic matter, such as wood- and grass-derived biochar (Keiluweit et al., 2010), fresh and aged biochar (Singh et al., 2014), and biochar added to typic udic ferrisols (Lin et al., 2018). Scanning transmission X-ray microscopy (STXM), with a spatial precision of $50 \mathrm{~nm}$, has been used to good effect in probing the composition and valence state of transition metals on the surface of intact particles of, and characterizing the $\mathrm{Cr}(\mathrm{III})$ and $\mathrm{Cr}(\mathrm{VI})$ distribution on, a carbon-coated montmorillonite nanocomposite (Wei et al., 2019). However, the simultaneous application of advanced spectroscopy techniques (XANES, STXM) and classic instrumental analysis (FTIR, XRD, and SEM-EDS) to analyzing biochar properties and metal sorption mechanisms is not well documented.

Jerusalem artichoke is widely cultivated in saline and desertified regions of Northern China. The tubers of this pioneer halophyte are used for the industrial production of fructose, inulin, and ethanol (Chi et al., 2011; Li and Chan-Halbrendt, 2009). As a result, disposal of its lignin-rich stalk residues becomes problematic. At the same time, copper $(\mathrm{Cu})$ is a fungicide-linked contaminant of widespread occurrence in the agricultural soils and aquacultural wastewater of Northern China (Cao et al., 2016; Tu et al., 2018). Thus, converting Jerusalem artichoke stalks (JAS) to biochar and using the product as a soil amendment could provide a means of resolving both of these environmental issues.

In this study, we used JAS as a feedstock to produce biochar, and applied advanced spectroscopic techniques to assess the effect of pyrolysis temperature on the molecular properties, and $\mathrm{Cu}(\mathrm{II})$ sorption capacity, of the biochar. The outcome of this investigation would serve as a sound basis for using halophyte-derived biochar to remediate $\mathrm{Cu}$-contaminated soils and wastewater.

\section{Materials and methods}

\subsection{Biomass source and biochar preparation}

Jerusalem artichoke stalks, collected from an experimental field near Yantai city, Shandong province, China were washed with tap water in order to remove adhering soil and dust. After air-drying for $2 \mathrm{~d}$, the stalks were dried in an electric oven at $80^{\circ} \mathrm{C}$ for $48 \mathrm{~h}$, ground, and passed through a $0.25 \mathrm{~mm}$ sieve. The powdered feedstock was packed into a ceramic crucible, and pyrolyzed at 300 , 500 and $700{ }^{\circ} \mathrm{C}$ for $6 \mathrm{~h}$ in an electric quartz tube furnace under a flow of purified nitrogen (99.99\%). The biochar samples so produced, denoted as JAS300, JAS500 and JAS700, were ground, passed through a $0.25 \mathrm{~mm}$ sieve, and stored in a desiccator before use.

\subsection{Sorption experiments}

The $\mathrm{Cu}$ sorption experiments were performed by adding $20 \mathrm{~mL}$ working solution to $10.0 \mathrm{mg}$ biochar in $50 \mathrm{~mL}$ polypropylene centrifuge tubes. A stock solution of $\mathrm{Cu}(\mathrm{II})$ was prepared by dissolving $5.00 \mathrm{~g}$ of $\mathrm{AR}$ grade $\mathrm{CuSO}_{4} \cdot 5 \mathrm{H}_{2} \mathrm{O}$ in $1 \mathrm{~L}$ of deionized water, and storing at $4{ }^{\circ} \mathrm{C}$. Working solutions of $\mathrm{Cu}(\mathrm{II})$ were made up by diluting the stock solution with $0.01 \mathrm{M} \mathrm{NaNO}_{3}$ serving as background electrolyte. The effect of $\mathrm{pH}$ was assessed by measuring sorption at an initial $\mathrm{pH}$ of 2.0,3.0, 4.0, 5.0, and 6.0. As shown in Fig. S1a in Supplementary Information (SI), all three biochars had a relatively high adsorption capacity for $\mathrm{Cu}$ (II) at $\mathrm{pH} 5$. Therefore, the kinetic and sorption isotherms experiments were performed at a pre-adjusted $\mathrm{pH}$ of $5.0 \pm 0.1$. $\mathrm{HNO}_{3}$ or $\mathrm{NaOH}$ solutions (0.01 and $0.1 \mathrm{M}$ ) were used to adjust solution $\mathrm{pH}$. Sorption kinetics were determined by placing a solution with an initial $\mathrm{Cu}(\mathrm{II})$ concentration of $25.0 \mathrm{mg} \mathrm{L}^{-1}$, and shaking at $150 \mathrm{rpm}$ and $25^{\circ} \mathrm{C}$ in a thermostat shaker. Samples of the $\mathrm{Cu}(\mathrm{II})$ solution were taken at set intervals from 0.25 to $60 \mathrm{~h}$ to determine the time required to reach equilibrium. Sorption isotherms were determined using an initial $\mathrm{Cu}(\mathrm{II})$ concentration of $1.0,2.5,5.0,10.0,25.0,50.0,75.0,100.0$, $125.0 \mathrm{mg} \mathrm{L}^{-1}$, and shaking at $25 \pm 1{ }^{\circ} \mathrm{C}$ for $24 \mathrm{~h}$. All sorption experiments were done in triplicate. The tubes were then centrifuged, and the equilibrium solutions were passed through $0.45 \mu \mathrm{m}$ polytetrafluoroethylene filters. The $\mathrm{Cu}$ concentration in the filtrate was analyzed using an inductively coupled plasma source mass spectrometer (ICP-MS, ELAN DRC II, PerkinElmer, USA), while the biochar residues were freeze-dried. According to the $\mathrm{Cu}$ sorption isotherms, the three biochars approximately reached their maximum sorption capacities when the initial concentration was $50.0 \mathrm{mg} \mathrm{L}^{-1}$ (SI Fig. S2). Hence the biochar residues from these points were chosen for further characterization.

The pseudo-first order, pseudo-second order, and Elovich models were tested to describe the kinetics of $\mathrm{Cu}(\mathrm{II})$ sorption (Wang et al., 2015; Zhang and Stanforth, 2005), while the Langmuir and Freundlich models were used to fit the isotherms for the sorption of $\mathrm{Cu}$ (II) to biochar. Details of the mathematical models used are listed in SI. Results are expressed as averages of replicate analyses with the corresponding standard deviations. OriginPro 8.0 was used to fit the sorption data and produce the figures.

\subsection{Characterization of biochar}

The concentration of bulk elements $(\mathrm{C}, \mathrm{H}, \mathrm{N}, \mathrm{S})$ in the biochar samples was determined using an MicroCube elemental analyzer (Elementar, Germany), while that of $\mathrm{K}, \mathrm{Na}, \mathrm{Ca}$ and $\mathrm{Mg}$ was measured using ICP-MS after hot acid digestion (Luo et al., 2014). Ash contents were measured by heating the biochar samples in a muffle furnace at $800^{\circ} \mathrm{C}$ for $8 \mathrm{~h}$. The $\mathrm{pH}$ of biochar was determined at a solid:water ratio of 1:100 (w/v) using a pH meter (FE20 plus, Mettler Toledo, Switzerland) after shaking the suspension for $24 \mathrm{~h}$ at $150 \mathrm{rpm}$. The specific surface area $\left(\mathrm{S}_{\mathrm{BET}}\right)$ was determined by sorption of $\mathrm{N}_{2}$ at $77 \mathrm{~K}$, using a Micromeritics ASAP 2020M + C analyzer, and applying the Brunauer-Emmett-Teller equation. The content of acidic functional groups (carboxyl and phenolic hydroxyl) was determined using the International Humic Substances Society titration method (IHSS, 2016).

FTIR analysis was carried out by mixing individual biochar with $\mathrm{KBr}$ to give a mass ratio of $1 \%$, pressing the mixture into a wafer, and recording the spectra in an FT/IR-4100 spectrometer (Jasco, Japan) with a resolution of $2 \mathrm{~cm}^{-1}$ over the $400-4000 \mathrm{~cm}^{-1}$ wavenumber region. The surface micromorphology and elemental content of the samples were analyzed using SEM (S-4800, Hitachi, Japan) and EDS (EX-350, HORIBA, Japan).

\subsection{STXM and XANES analysis}

X-ray imaging and spectromicroscopy, together with the $\mathrm{Cu}\left(\mathrm{L}_{3}-\right.$ edge) and C (K-edge) XANES data collection were performed using the STXM beamline (BL08U1A) at the Shanghai Synchrotron Radiation Facility, China. The spectra of $\mathrm{Cu}$ references were used to identify the oxidation state of $\mathrm{Cu}$ on the biochar surface (SI Fig. S3). Samples for analysis were prepared in an anaerobic glove box in order to prevent oxidation. $\mathrm{CuO}$ and $\mathrm{Cu}_{2} \mathrm{O}$ were chosen as $\mathrm{Cu}$ references. The XANES and STXM measurements were carried out at the end station of an ultra-high vacuum chamber operating at the 
$10^{-5}$ Torr range. For $\mathrm{Cu}$ and $\mathrm{C}$ XANES spectra measurement, ground biochar samples and $\mathrm{Cu}$ references powders were dispersed in boiled deionized water and deposited onto gold-sprayed silicon wafers. Spectra were recorded from 925 to $950 \mathrm{eV}$ for $\mathrm{Cu}$ (L $\mathrm{L}_{3}$-edge) and from 280 to $310 \mathrm{eV}$ for C (K-edge) in steps of $0.2 \mathrm{eV}$. In addition, three spectra were recorded at spots outside the sample area for background correction. All the spectra were collected in the total electron yield mode, and the average of three scans or more was taken. A semiquantitative analysis of C XANES spectra was carried out by peak deconvolution using the PeakFit (V4.12) program (Wei et al., 2019). STXM analysis was performed on ground biochar samples attached to $\mathrm{Si}_{3} \mathrm{~N}_{4}$ windows. Two-dimensional distributions of $\mathrm{Cu}(\mathrm{II}) / \mathrm{Cu}(\mathrm{I})$ in the selected areas on biochar were obtained by a dual energy contrast imaging method using IDL 7.0.6 software (Wei et al., 2019).

\section{Results and discussion}

\subsection{Biochar characterization}

The physical and chemical properties of the biochar samples are summarized in Table 1 and SI Table S1. Biochar yields declined with a rise in pyrolysis temperature, but the ash content and $\mathrm{pH}$ of the biochar increased with temperature (Table 1 ). Moreover, the $\mathrm{C}$ content of the biochar samples increased from 300 to $700{ }^{\circ} \mathrm{C}$ but the $\mathrm{H}$ and $\mathrm{O}$ contents decreased as did the $\mathrm{H} / \mathrm{C}$ and $\mathrm{O} / \mathrm{C}$ atomic ratios. The polarity index $((\mathrm{O}+\mathrm{N}) / \mathrm{C}$ ratio $)$ also decreased, reflecting a reduction in the concentration of polar functional groups with a rise in pyrolysis temperature (Qian and Chen, 2013). At the same time, the titration results showed a parallel decrease in the content of acidic functional groups (Table 1). These observations suggest that biochar formation involves dehydration and dehydrogenation of the lignocellulosic feedstock accompanied by carbonaceous condensation (Keiluweit et al., 2010; Qian and Chen, 2013).

\subsubsection{Organic C structures of JAS biochar}

Fig. 1 shows the FTIR spectra of the biochar samples, while Fig. 2 displays the corresponding C K-edge XANES spectra. The various peaks and their respective assignments are summarized in Table 2.

FTIR has been widely used to assess the evolution of organic C structures in biochar as a function of pyrolysis temperature (Keiluweit et al., 2010; Park et al., 2015; Qian and Chen, 2013). In the present instance, the intensity of the $\mathrm{O}-\mathrm{H}$ band $\left(3200-3600 \mathrm{~cm}^{-1}\right)$ decreased with an increase in pyrolysis temperature. At the same time, the carboxylate $\left(\mathrm{COO}^{-}\right)$band was shifted to lower wavenumbers from $1604 \mathrm{~cm}^{-1}$ (for JAS300) through $1587 \mathrm{~cm}^{-1}$ (for JAS500) to $1566 \mathrm{~cm}^{-1}$ (for JAS700). These findings are indicative of a progressive weakening of $\mathrm{H}$-bonding as the pyrolysis temperature increases. The FTIR spectrum of JAS300 showed a band at $1510 \mathrm{~cm}^{-1}$ assigned to aromatic $\mathrm{C}=\mathrm{C}$ vibration of cellulose. The absence of this band in the spectra of JAS500 and JAS700 could be attributed to the decomposition of cellulose at $315-400{ }^{\circ} \mathrm{C}$ (Yang et al., 2007). There was also a narrowing of the aliphatic $\mathrm{C}-\mathrm{H}$ bands (at 2920 and $2850 \mathrm{~cm}^{-1}$ ) in the spectra of
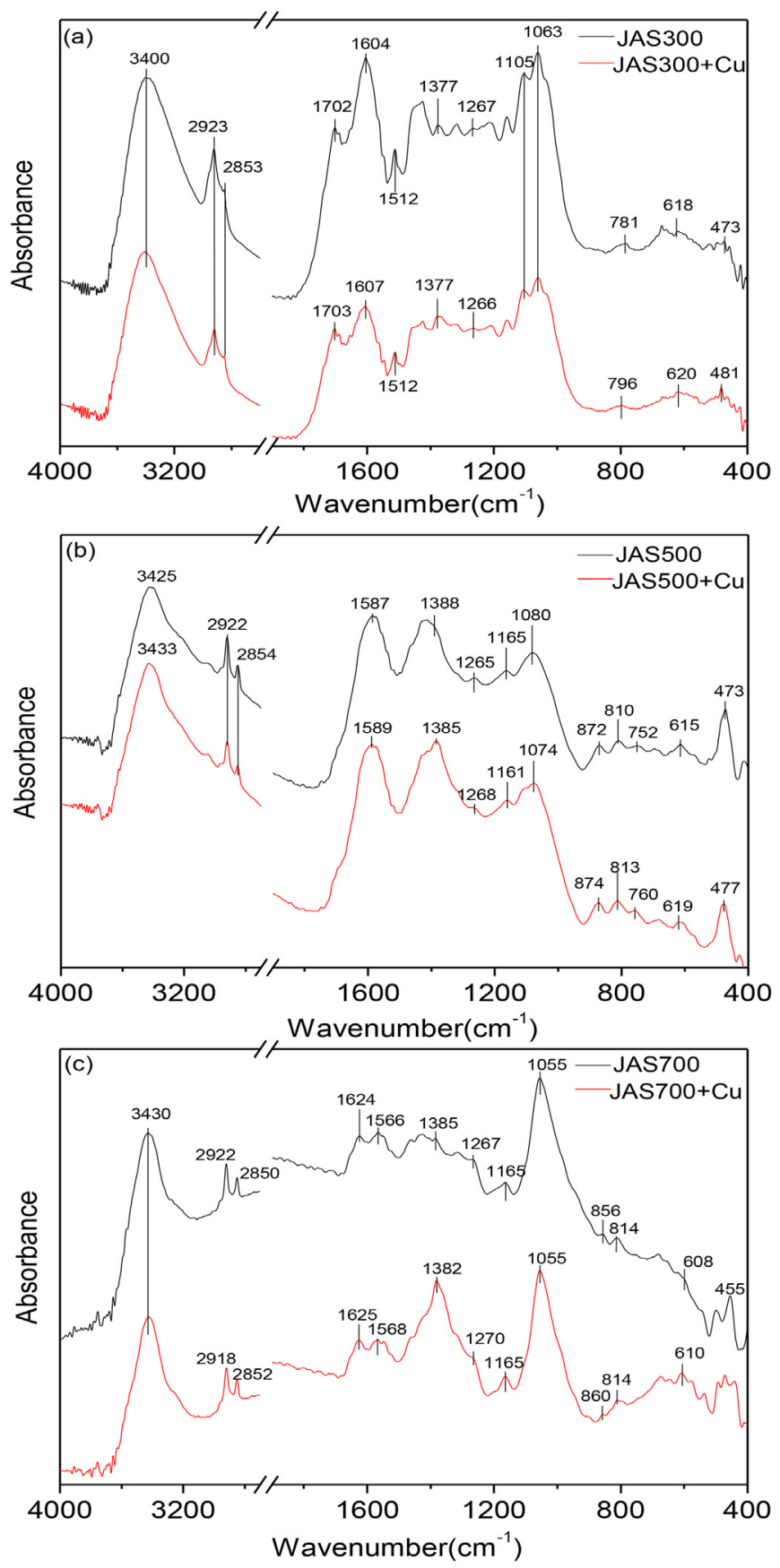

Fig. 1. FTIR spectra of (a) JAS 300, (b) JAS500, (c) JAS700 before and after Cu sorption.

JAS500 and JAS700 relative to that of JAS300, indicating a reduction in aliphatic alkyl concentration with rising temperature. Also noteworthy was the appearance in the spectra of JAS500 and

Table 1

Physical and chemical properties of the JAS biochars.

\begin{tabular}{|c|c|c|c|c|c|c|c|c|c|c|c|c|c|c|}
\hline \multirow[t]{2}{*}{ Biochar } & \multirow[t]{2}{*}{ Yield $^{\mathrm{a}}(\%)$} & \multirow[t]{2}{*}{ Ash (\%) } & \multirow[t]{2}{*}{$\mathrm{pH}$} & \multirow[t]{2}{*}{$\mathrm{S}_{\mathrm{BET}} \mathrm{m}^{2} \mathrm{~g}^{-1}$} & \multicolumn{5}{|c|}{ Elemental content (\%) } & \multicolumn{3}{|c|}{ Atomic ratio } & \multirow{2}{*}{$\frac{-\mathrm{COOH}}{\mathrm{mol} \mathrm{kg}^{-1}}$} & \multirow[t]{2}{*}{ Phenolic-OH } \\
\hline & & & & & $\mathrm{C}$ & $\mathrm{H}$ & 0 & $\mathrm{~N}$ & $S$ & $\mathrm{H} / \mathrm{C}$ & $\mathrm{O} / \mathrm{C}$ & $(\mathrm{O}+\mathrm{N}) / \mathrm{C}$ & & \\
\hline JAS300 & 45.21 & 5.38 & 6.92 & 7.04 & 57.99 & 5.04 & 30.23 & 0.73 & 0.63 & 1.04 & 0.39 & 0.40 & 3.21 & 1.63 \\
\hline JAS500 & 32.67 & 10.40 & 9.67 & 8.51 & 70.37 & 3.08 & 25.16 & 0.96 & 0.43 & 0.52 & 0.27 & 0.28 & 1.95 & 0.78 \\
\hline JAS700 & 30.15 & 12.23 & 10.09 & 7.07 & 73.67 & 1.82 & 12.69 & 0.88 & 0.53 & 0.30 & 0.13 & 0.14 & 0.93 & 0.41 \\
\hline
\end{tabular}

\footnotetext{
${ }^{\text {a }}$ Denotes the dry mass of biochars divided by the dry mass of the precursor loaded into the crucible.
} 

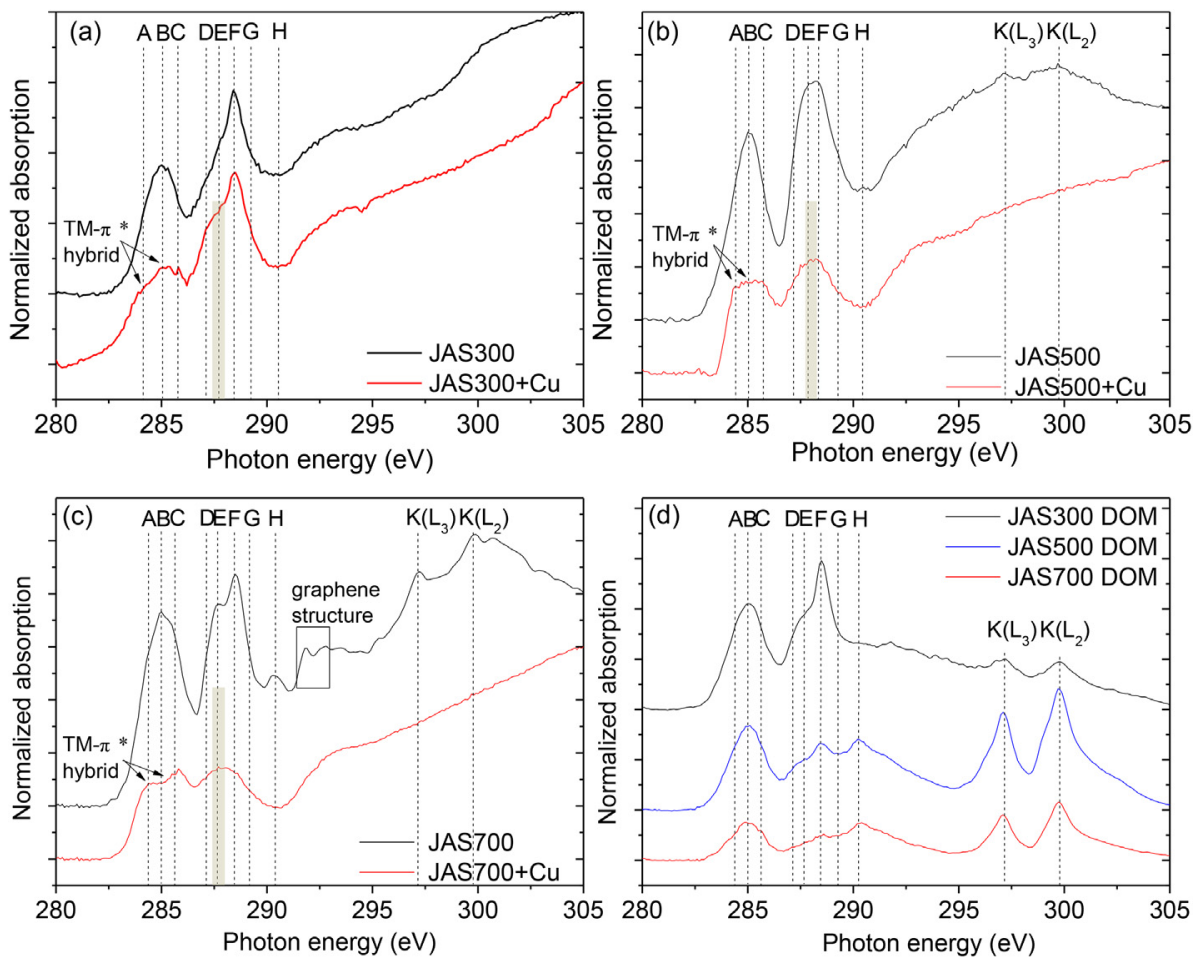

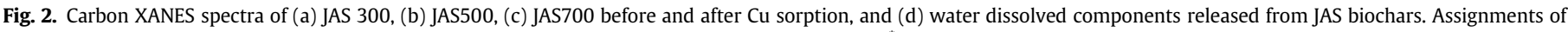

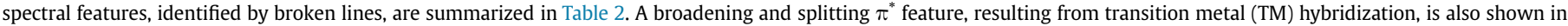

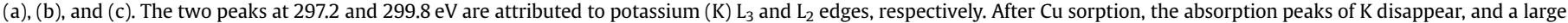
amount of $\mathrm{K}$ was found in the dissolved components from JAS biochar.

Table 2

Peak assignments ${ }^{\mathrm{a}}$ for C species obtained from FTIR and C K-egde XANES spectroscopy.

\begin{tabular}{|c|c|}
\hline Energy level & Assignments \\
\hline \multicolumn{2}{|l|}{ FTIR $\left(\mathrm{cm}^{-1}\right)$} \\
\hline $3600-3200$ & $\mathrm{O}-\mathrm{H}$ stretching of hydrogen bonded $\mathrm{O}-\mathrm{H}$ \\
\hline $2930-2850$ & $\mathrm{C}-\mathrm{H}$ stretching of aliphatic $\mathrm{CH}_{\mathrm{x}}, \mathrm{x}=1,2,3$ \\
\hline $1700 \pm 10$ & $\mathrm{C}=\mathrm{O}$ stretching of carboxylic acid, aldehydes, ketones and esters \\
\hline $1600 \pm 40$ & - COO- asymmetric stretching of carboxylic acid \\
\hline $1570-1540$ & $\mathrm{C}=\mathrm{O}$ stretching of conjugated systems like ketones and quinones \\
\hline $1510 \pm 10 ; 1440 \pm 20$ & vibration of $C=C$ in aromatic ring, cellulose \\
\hline $1380 \pm 10$ & - COO- symmetric stretching of carboxylic acid \\
\hline $1260 \pm 10$ & $\mathrm{C}-\mathrm{O}$ stretching of phenolic \\
\hline $1165 \pm 10$ & $\mathrm{C}-\mathrm{O}$ stretching of $\mathrm{C}-\mathrm{O}-\mathrm{C}$ ester groups \\
\hline $1100-1000$ & $\mathrm{Si}-\mathrm{O}-\mathrm{Si}$ asymmetric stretching of silica compounds \\
\hline $800 \pm 20$ & $\mathrm{Si}-\mathrm{O}-\mathrm{Si}$ symmetric stretching of silica compounds \\
\hline $860 \pm 20 ; 810 \pm 20 ; 760 \pm 20$ & $\mathrm{C}-\mathrm{H}$ bending of aromatic compounds associated with furan and pyridine \\
\hline $610 \pm 10$ & asymmetric triply degenerate $(\mathrm{O}-\mathrm{P}-\mathrm{O})$ bending for the $\mathrm{PO}_{4}^{3-}$ \\
\hline $470 \pm 20$ & $\mathrm{Si}-\mathrm{O}-\mathrm{Si}$ bending of silica compounds \\
\hline \multicolumn{2}{|l|}{ C K-egde XANES (eV) } \\
\hline $283.5-284.3$ (A peak) & $1 \mathrm{~s}-\pi^{*} \mathrm{C}=\mathrm{O}$ transitions of aromatic quinones \\
\hline $284.7-285.3$ (B peak) & $1 \mathrm{~s}-\pi^{*} \mathrm{C}=\mathrm{C} / \mathrm{C}-\mathrm{H}$ transitions of aromatic hydrocarbons \\
\hline $285.5-286.2$ (C peak) & $1 \mathrm{~s}-\pi^{*} \mathrm{C}=\mathrm{O}$ transitions of carbonyl substituted aromatic structures of quinones and ketones \\
\hline $286.6-287.1$ (D peak) & $1 \mathrm{~s}-\pi^{*} \mathrm{C}=\mathrm{C}$ transitions of aromatic $\mathrm{C}-\mathrm{OH}$ in phenols \\
\hline $287.5-287.9$ (E peak) & $1 \mathrm{~s}-\sigma^{*} / 3 \mathrm{p}_{\mathrm{C}-\mathrm{H}}$ transitions of aliphatic hydrocarbons; $1 \mathrm{~s}-\pi^{*}{ }_{\mathrm{C}}={ }_{\mathrm{O}}$ transitions of carbonyl functionalities from aromatic ketones \\
\hline $288.2-288.6$ (F peak) & $1 \mathrm{~s}-\pi^{*} \mathrm{C}=\mathrm{O}$ transitions of carboxyl \\
\hline $288.9-289.5$ (G peak) & $1 \mathrm{~s}-3 \mathrm{p} / \sigma^{*} \mathrm{C}-\mathrm{O}$ transitions of $\mathrm{O}$-alkyl of alcohols, hemicellulose and cellulose, propyl side chains and methoxyl carbons of lignin \\
\hline $290.0-290.5$ (H peak) & $1 \mathrm{~s}-\pi^{*} \mathrm{C}=\mathrm{O}$ transitions of carbonyl; carbonate \\
\hline $291.0-295.0$ & $1 \mathrm{~s}-\sigma^{*} \mathrm{C}-\mathrm{C}$ transitions of aromatics, extensive conjugated aromatic sheets \\
\hline
\end{tabular}

a FTIR peak assignments were adapted from Keiluweit et al. (2010); Park et al. (2015); Wei et al. (2019); C K-egde XANES peak assignments were adapted from Keiluweit et al. (2010); Solomon et al. (2012); Singh et al. (2014); Wei et al. (2019).

JAS700 of a $\gamma-\mathrm{CH}$ band near $860 \mathrm{~cm}^{-1}$ due to furan. The presence in the spectrum of JAS700 of a $\mathrm{C}=\mathrm{O}$ band between 1570 and $1540 \mathrm{~cm}^{-1}$, due to conjugated ketones and quinones, suggests that a high pyrolysis temperature is conducive to aromatization and condensation (Keiluweit et al., 2010). Thus, JAS500 and JAS700 are poorer in organic functional groups than the biochar produced by pyrolysis at $300^{\circ} \mathrm{C}$.

Based on previous data for biochar, black carbon (Keiluweit 
et al., 2010; Lin et al., 2018; Singh et al., 2014; Solomon et al., 2012), and soil organic substances (Luo et al., 2017; Sedlmair et al., 2012), the peaks in the C K-edge XANES spectra of JAS biochars could be assigned to eight types of organic carbon species, namely, quinonic$\mathrm{C}$, aromatic- $\mathrm{C}$, ketonic- $\mathrm{C}$, phenolic- $\mathrm{C}$, aliphatic-C/carbonyl-C, carboxyl-C, O-alkyl-C, and carbonyl-C/carbonate (Table 2, Fig. 2). All three JAS biochar samples showed a prominent peak for aromatic-C (Fig. 2, peak A at $284.8 \mathrm{eV}$ ) and carboxyl-C (Fig. 2, peak F at $288.5 \mathrm{eV}$. Spectral deconvolution indicated that the former accounts for $20.25 \%-24.25 \%$ and the latter for $20.09 \%-22.78 \%$ of total organic C (Table 3, SI Fig. S4).

C K-edge XANES analysis can further delineate changes in the relative abundance of $C$ functional groups in the biochar samples. With an increase in pyrolysis temperature, the proportion of quinonic- $C$ and aromatic-C increased, while that of carboxyl-C and phenolic-C declined (Table 3). This finding was consistent with an increase in biochar aromaticity. The spectrum of JAS700 showed a peak of $1 \mathrm{~s}-\pi^{*}{ }_{\mathrm{C}}={ }_{\mathrm{C} / \mathrm{C}-\mathrm{H}}$ transition centered at $284.8 \mathrm{eV}$, a sharp peak of $1 \mathrm{~s}-\sigma^{*}{ }^{*}-{ }^{-}$transition at $291.5 \mathrm{eV}$, and a second, broader $1 \mathrm{~s}-\sigma^{*}{ }^{*}-\mathrm{c}$ transition at $292.5 \mathrm{eV}$ (Brandes et al., 2008). This observation is strongly indicative of extensive aromatization, condensation, and the formation of graphene-like structures (Fig. 2c). In a previous study (Wei et al., 2018), we also found that biochar produced at a high temperature contained much less water-soluble carbon than the material formed at a low temperature. Further, the watersoluble carbon was highly aromatic but poor in carboxyl groups (Fig. 2d). In accordance with the titration results, the $C$ XANES spectra of the biochar samples confirmed that high-temperature pyrolysis led to an appreciable reduction in the concentration of acidic functional groups (Fig. 2, Table 1).

\subsubsection{Mineral components of JAS biochar}

The Jerusalem artichoke feedstock came from plants grown on coastal saline soils from which the plants tend to take much calcium to improve their salt stress tolerance (Saijo et al., 2001). Supplementary Table S1 indeed shows that the JAS-derived biochars were highly enriched in calcium. Furthermore, the peaks of $\mathrm{K}$ $\mathrm{L}_{3}$ and $\mathrm{L}_{2}$ edges in the C XANES spectra of the biochar (Fig. 2) became more prominent with an increase in pyrolysis temperature from 300 to $700{ }^{\circ} \mathrm{C}$, indicative of a marked increase in $\mathrm{K}$ content. The content of other mineral elements such as $\mathrm{Na}$ and $\mathrm{Mg}$ also increased with pyrolysis temperature (Table S1). This accumulation of mineral elements in biochar with a rise in pyrolysis temperature was conducive to mineral formation.

XRD analysis showed the presence of calcite in JAS300 and JAS500 but not in JAS700 where anorthite is the predominant Carich mineral (Fig. 3). SEM and element EDS analyses further indicated the presence in the biochar samples of nano-size $(\sim 50 \mathrm{~nm})$ particles, containing $\mathrm{Ca}, \mathrm{Mg}, \mathrm{K}, \mathrm{P}$ and $\mathrm{Si}$, forming scattered aggregates (SI Fig. S5). Following previous studies (Qian and Chen, 2013; Thyrel et al., 2016; Xu et al., 2017), these particles could be identified with such mineral crystalloids as $\mathrm{K}_{2} \mathrm{CaCO}_{3}, \mathrm{Ca}_{5}\left(\mathrm{PO}_{4}\right)_{3}(\mathrm{OH})$, $\mathrm{Ca}_{2} \mathrm{Mg}\left(\mathrm{PO}_{4}\right)_{2} \cdot 2 \mathrm{H}_{2} \mathrm{O}$, and $\mathrm{CaMgSi}_{2} \mathrm{O}_{6}$.

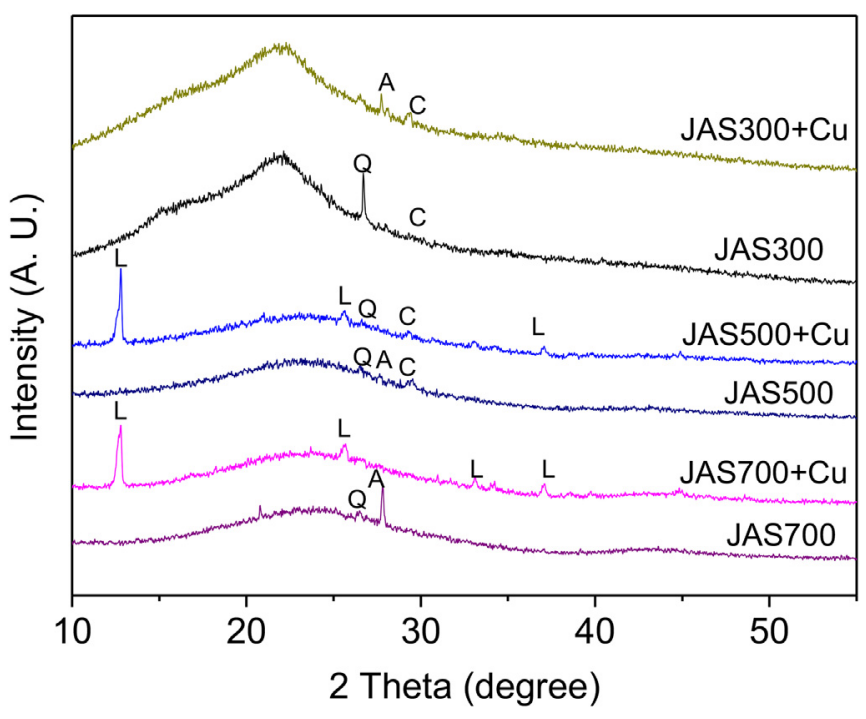

Fig. 3. X-ray diffraction patterns of the JAS biochars produced at 300,500 , and $700{ }^{\circ} \mathrm{C}$ before and after $\mathrm{Cu}$ sorption. $\mathrm{A}=$ anorthite; $\mathrm{C}=$ calcite; $\mathrm{L}=$ langite; $\mathrm{Q}=$ quartz.

\subsection{Cu sorption}

The sorption isotherms of $\mathrm{Cu}$ are presented in SI Fig. S2, and the fitting parameters of the Freundlich and Langmuir models are summarized in SI Table S2. The Cu sorption isotherm of JAS300 conformed well to the Langmuir model $\left(R^{2}=0.963\right)$, while the isotherms of JAS500 and JAS700 fitted better into the Freundlich model $\left(\mathrm{R}^{2}=0.933,0.956\right)$. These results suggest that $\mathrm{Cu}$ sorption took place at homogeneous sites in low temperature biochar, but at heterogeneous sites (such as mineral constituents) in high temperature biochar. (Ho et al., 2002; Xu et al., 2017). The maximum sorption capacity $\left(\mathrm{Q}_{\mathrm{m}}\right)$ of the three biochars decreased in the order of JAS300 (17.0 $\left.\mathrm{mg} \mathrm{g}^{-1}\right)>$ JAS700 $\quad\left(15.2 \mathrm{mg} \mathrm{g}^{-1}\right)>$ JAS500 $\left(11.1 \mathrm{mg} \mathrm{g}^{-1}\right)$. The $\mathrm{Cu} \mathrm{Q}_{\mathrm{m}}$ of all JAS biochars was superior to that of biochars produced at $\sim 400^{\circ} \mathrm{C}$ from such feedstocks as canola straw $\left(0.59 \mathrm{mg} \mathrm{g}^{-1}\right)$, soybean straw $\left(0.83 \mathrm{mg} \mathrm{g}^{-1}\right)$, and hardwood $\left(6.79 \mathrm{mg} \mathrm{g}^{-1}\right)$ under similar sorption conditions $\left(\mathrm{pH} 5.0,25^{\circ} \mathrm{C}\right)$ (Tan et al., 2015). Among the three JAS biochars, JAS300 exhibited the best sorption performance. Uchimiya et al. (2011) have reported similarly for biochars obtained from cottonseed hull $(\mathrm{CH})$ in lowering $\mathrm{Cu}$ concentration in soil solutions in the order of $\mathrm{CH} 350>\mathrm{CH} 500 \approx \mathrm{CH} 650>\mathrm{CH} 800$. On the other hand, Li et al. (2015) reported that the Cu sorption capacity of biochar, derived from water hyacinth and saltmarsh cordgrass, increased with a rise in pyrolysis temperature from 200 to $700{ }^{\circ} \mathrm{C}$. It would therefore appear that $\mathrm{Cu}$ sorption is influenced not only by the pyrolysis temperature but also by the nature of the biomass feedstock.

Fig. 4 shows the kinetics of $\mathrm{Cu}$ sorption to the JAS-derived biochars. Cu sorption to JAS300 increased rapidly during the first $6 \mathrm{~h}$, and then slowly until equilibrium was attained. In the case of JAS500 and JAS700, Cu sorption increased rapidly up to $12 \mathrm{~h}$, and

Table 3

C species proportions and aromaticity of JAS biochars.

\begin{tabular}{|c|c|c|c|c|c|c|c|c|c|c|}
\hline \multirow[t]{2}{*}{ Biochar } & \multicolumn{8}{|c|}{ C species proportions (\%) } & \multirow[t]{2}{*}{ Total aromatic } & \multirow[t]{2}{*}{ Aromaticity ${ }^{a}$} \\
\hline & Quinonic-C & Aromatic-C & Ketonic-C & Phenolic-C & Aliphatic-C/Carbonyl-C & Carboxyl-C & O-alkyl-C & Carbonyl-C/carbonate & & \\
\hline JAS300 & 6.43 & 13.82 & 12.10 & 10.29 & 14.62 & 22.78 & 11.60 & 8.36 & 20.25 & 0.89 \\
\hline JAS500 & 6.49 & 15.31 & 12.86 & 5.50 & 19.73 & 20.09 & 11.91 & 8.10 & 21.81 & 1.09 \\
\hline JAS700 & 9.08 & 15.17 & 13.46 & 6.21 & 18.24 & 21.15 & 8.43 & 8.26 & 24.25 & 1.15 \\
\hline
\end{tabular}

\footnotetext{
${ }^{\mathrm{a}}$ Aromaticity $=$ total aromatic- $\mathrm{C} /$ carboxyl-C; total aromatic- $\mathrm{C}=$ quinonic- $\mathrm{C}+$ aromatic- $\mathrm{C}$.
} 

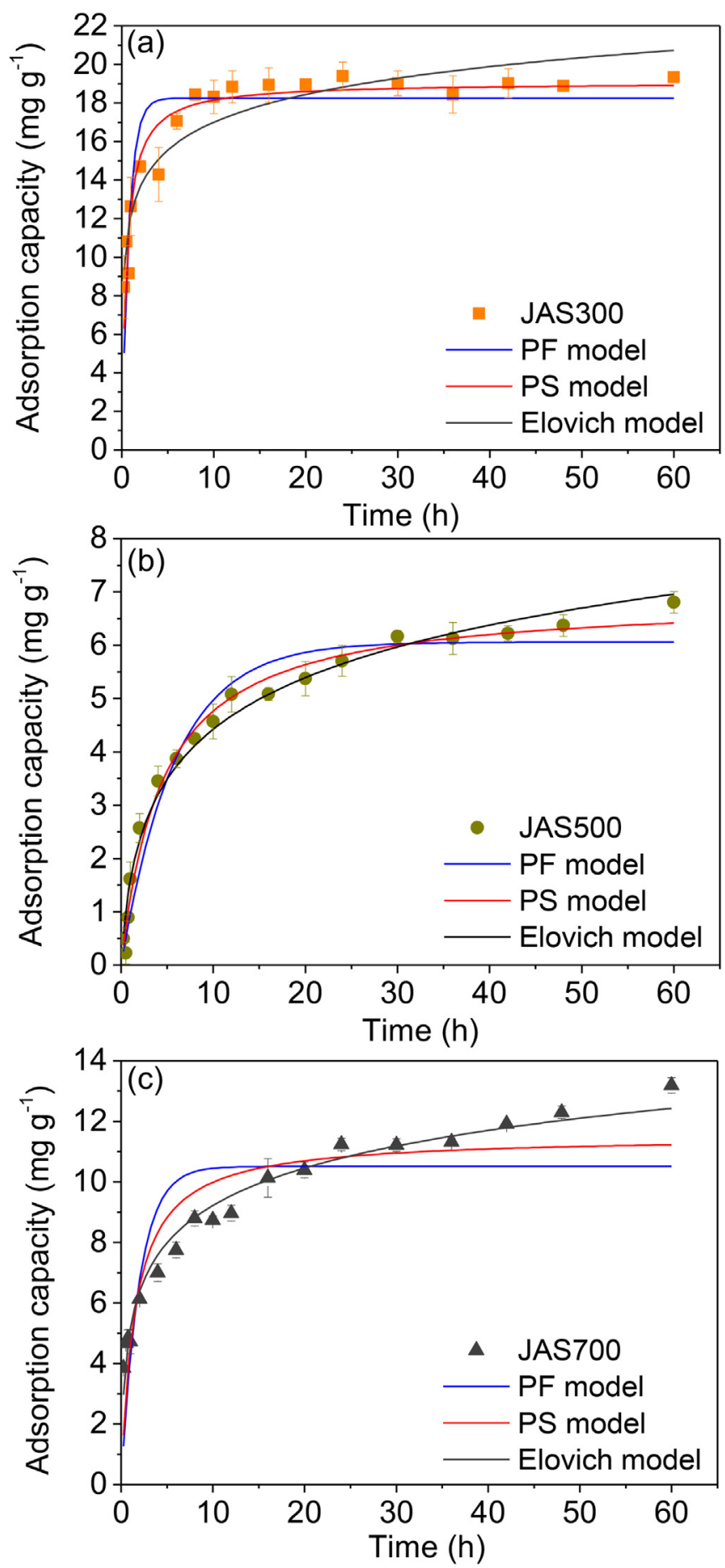

Fig. 4. Kinetics curves for the sorption of $\mathrm{Cu}$ to JAS biochars produced at 300,500 , and $700^{\circ} \mathrm{C}$.

then slowed down during the next $48 \mathrm{~h}$. The fitting parameters of the PF order model, PS order model, and Elovich equation for the kinetics of $\mathrm{Cu}$ sorption are listed in SI Table S3.

On the basis of the corresponding $\mathrm{R}^{2}$ values, the PS order model gave the best fit for JAS300 $\left(R^{2}=0.908\right)$, while the Elovich equation well described the Cu sorption kinetics for both JAS500 $\left(R^{2}=0.986\right)$ and JAS700 $\left(\mathrm{R}^{2}=0.974\right)$. The PF order model describes the kinetics of diffusion-controlled adsorption, while the PS order model assumes that the rate-limiting step is due to chemical reaction between sorbent and sorbate (Ho, 2006), and the Elovich equation rests on the assumption that the kinetics is controlled by a heterogeneous surface reaction (Zhang and Stanforth, 2005).

The isotherms and kinetics fitting results would indicate the involvement of various chemical reactions in the $\mathrm{Cu}(\mathrm{II})$-biochar interaction. $\mathrm{Cu}$ sorption is also favored by the porous structure, and heterogeneous surface properties, of the biochars. The application of FTIR, C K-edge XANES, STXM, and XRD to analyzing the biochar samples before and after sorption of $\mathrm{Cu}(\mathrm{II})$ provided further insight into the underlying mechanisms.

\subsection{Sorption mechanisms}

\subsubsection{Reduction of $\mathrm{Cu}(\mathrm{II})$ to $\mathrm{Cu}(\mathrm{I})$}

Biochar contains constituents capable of accepting and donating electrons in the form of quinones, phenolic compounds, and polycondensed aromatic structures with a conjugated $\pi$-electron system (Prévoteau et al., 2016; Sumaraj and Padhye, 2017). The ability of biochar to reduce variable-valence metals has previously been linked to the high electron-donating capacity of the sorbent (Yuan et al., 2017). Bogusz et al. (2015) carried out Cu(II) sorption experiment using industrially and lab-prepared biochars produced from wheat straw at $700{ }^{\circ} \mathrm{C}$. XPS indicated the presence of mixed species of $\mathrm{Cu}(\mathrm{II})$ and $\mathrm{Cu}(\mathrm{I})$ on the surfaces of both biochars. In the present study, the co-existence of $\mathrm{Cu}(\mathrm{II})$ and $\mathrm{Cu}(\mathrm{I})$ on the surface of all three biochars was further imaged by STXM (Fig. 5), and the reduction of $\mathrm{Cu}(\mathrm{II})$ to $\mathrm{Cu}(\mathrm{I})$ was more evident with JAS300 and JAS700 than with JAS500.

Pyrolysis temperature could affect the organic carbon structure of biochar and its metal reductive capacity (Klüpfel et al., 2014; Yuan et al., 2017). To the best of our knowledge, however, direct studies about the effects of organic carbon structure on $\mathrm{Cu}$ reduction are few in number. Using coconut coir biochar produced by pyrolysis over the temperature range of $250-600^{\circ} \mathrm{C}$, Shen et al. (2012) observed that the $\mathrm{Cr}(\mathrm{VI})$ sorption capacity of the samples declined with an increase in pyrolysis temperature. They suggested that biochar produced at low temperature was more enriched in oxygen-containing (carboxyl, lactonic, phenolic) functional groups capable of promoting the reduction of $\mathrm{Cr}(\mathrm{VI})$ and subsequent adsorption of the reduced species. Similarly, Xu et al. (2019) found that biochar derived from peanut shell at $350^{\circ} \mathrm{C}$ could effectively reduce $\mathrm{Cr}(\mathrm{VI})$ to $\mathrm{Cr}(\mathrm{III})$. And the $\mathrm{C}-\mathrm{O}$ and $\mathrm{C}=\mathrm{O}$ groups of biochar served as the electron donors for the $\mathrm{Cr}(\mathrm{VI})$ reduction.

In keeping with the findings by Shen et al. (2012) and Xu et al. (2019), the JAS300 sample had the highest content of surfacebound $\mathrm{Cu}(\mathrm{I})$ (Fig. 5b). FTIR and $\mathrm{C}$ K-edge XANES analysis further indicated that JAS300 was highly enriched in various oxygencontaining functional groups, capable of serving as electron donors. Although JAS700 was depleted in oxygen-containing groups (Fig. 1), the increased presence of polycondensed aromatic and graphene-like structures could facilitate electron transfer (Klüpfel et al., 2014) and the reduction of some $\mathrm{Cu}(\mathrm{II})$ to $\mathrm{Cu}(\mathrm{I})$. On the other hand, JAS500 was relatively inactive in this regard because of its low content of oxygen-containing groups and polycondensed aromatic structures.

\subsubsection{Surface complexation}

It is widely accepted that the carboxyl groups in biochar can serve as complexing agents for metal cations such as $\mathrm{Cu}(\mathrm{II})$ and $\mathrm{Cu}(\mathrm{I})$. The FTIR analysis showed that the asymmetric and symmetric $\mathrm{COO}^{-}$stretching frequencies were separated by $227 \mathrm{~cm}^{-1}$ for JAS300, $199 \mathrm{~cm}^{-1}$ for JAS500, and $239 \mathrm{~cm}^{-1}$ for JAS700 (Fig. 1). Following $\mathrm{Cu}$ sorption, the extent of separation amounted to 230 , 204 , and $243 \mathrm{~cm}^{-1}$, respectively. These observations are indicative of $\mathrm{Cu}$ chelation or bridging to carboxyl groups (Hay and Myneni, 
(a)

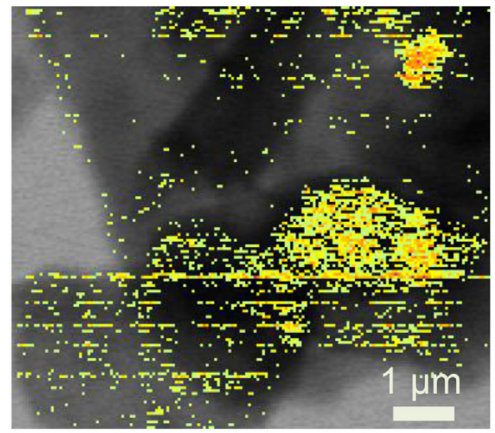

(c)

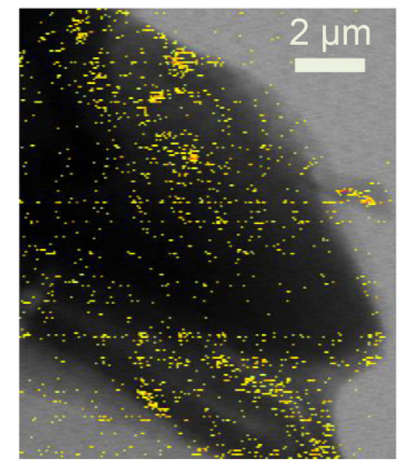

(e)

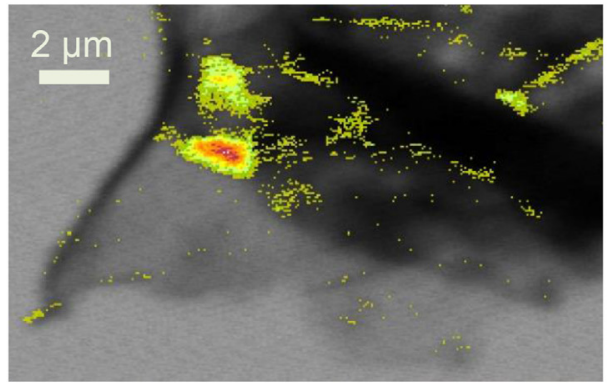

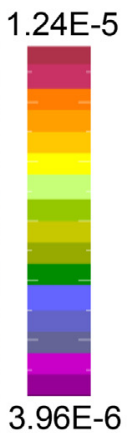

3.96E-6

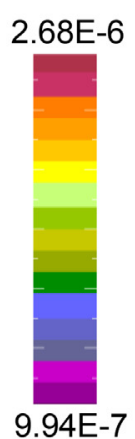

9.94E-7

2.44E-5

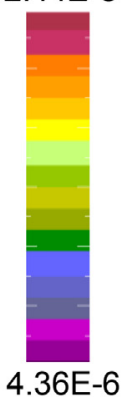

(b)

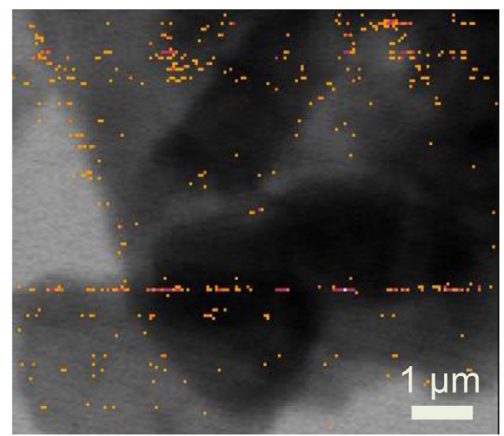

$1.22 \mathrm{E}-7$

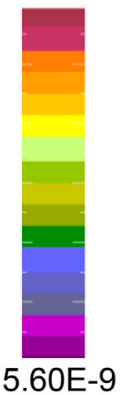

(d)

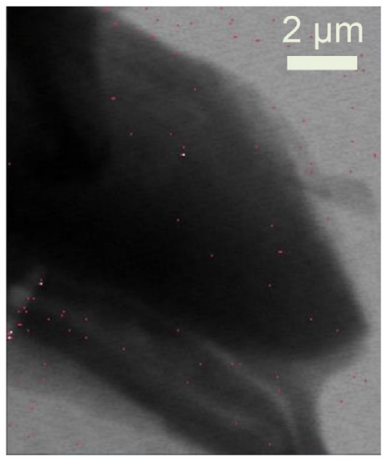

4.30E-9

(f)

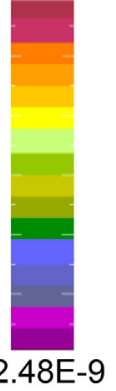

2.48E-9

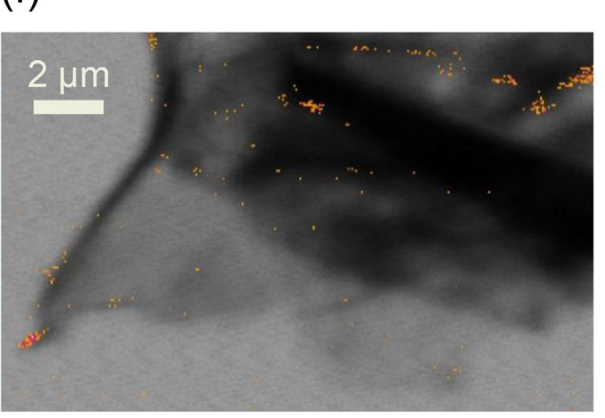

$8.41 \mathrm{E}-8$

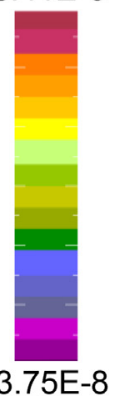

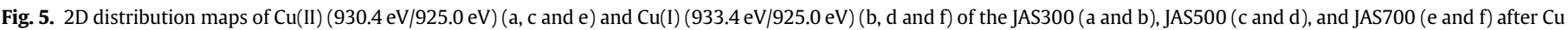

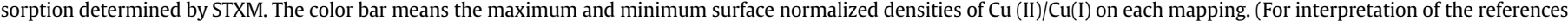
to color in this figure legend, the reader is referred to the Web version of this article.)

2007). Furthermore, the marked appearance of peaks near $1380 \mathrm{~cm}^{-1}$ in the spectra of biochar samples after Cu sorption was consistent with the formation of surface carboxylates (Dong et al., 2011).

Carbon K-edge XANES spectra collected for JAS biochars, loaded with $\mathrm{Cu}$, were clearly dissimilar to those observed for the original JAS biochars (Fig. 2). For the three JAS biochars, $\mathrm{Cu}$ association resulted in a pronounced decrease in carboxyl-C peak $\left(1 \mathrm{~s}-\pi^{*}{ }_{\mathrm{C}}={ }_{0}\right.$ transitions centered at $288.4 \mathrm{eV}$ ). Concomitantly, the feature at a lower energy region (gray areas at $286.8-287.8 \mathrm{eV}$ in Fig. 2 a, b, and c) was enhanced and broadened. These feature changes are strongly indicative of Cu cations interacting with carboxyl groups in the biochars. Complexation of polyvalent metal cations to the natural organic matter, i.e. dissolved organic matter and humic acid, similarly led to a reduction in carboxyl resonance intensity with a shoulder appearing approximately $1 \mathrm{eV}$ below the carboxyl peak (Armbruster et al., 2009; Sowers et al., 2018). For organometallic compounds containing d-electron metals such as $\mathrm{Fe}, \mathrm{Co}$, and $\mathrm{Ni}$, a sharp decrease of $\mathrm{C} 1 \mathrm{~s}-\pi^{*}{ }_{\mathrm{C}}={ }_{\mathrm{O}}$ oscillator strengths was observed in the inner-shell electron energy loss spectra of carbonyl carbon as compared to those of metal-free compounds due to $\mathrm{d} \pi$ - $\mathrm{p} \pi$ back-bonding (Hitchcock et al., 1990). Considering the various arrangements of carboxyl coordination (Deacon and Phillips, 1980), it is reasonable to hypothesize that the reduction of carboxyl $1 \mathrm{~s}-$ $\pi^{*}{ }_{C}=0$ resonances, in the presence of $\mathrm{Cu}$, partly resulted from $\mathrm{d} \pi$ $\mathrm{p} \pi$ interactions due to $\mathrm{Cu}-\pi$ bonding. However, the reason for the emergence of the accompanying feature is unclear.

Phenolic groups are also known to form complexes with $\mathrm{Cu}$ in carbonaceous materials (Li et al., 2015). Due to overlap by the feature at $286.8-287.8 \mathrm{eV}$, after loading with $\mathrm{Cu}$, it is hard to discern the changes in phenolic- $C 1 \mathrm{~s}-\pi^{*}{ }_{C}={ }_{C}$ resonances in the $C$ XANES spectra. However, the FTIR spectra showed that the peak attributed to phenolic- $\mathrm{OH}$ group stretching at 1264,1265 , and $1267 \mathrm{~cm}^{-1}$ for JAS300, JAS500, and JAS700, respectively, shifted to 1266,1268 , and $1270 \mathrm{~cm}^{-1}$ after $\mathrm{Cu}$ sorption. This observation suggests that phenolic groups also participate in Cu complexation. Compared to the high participation of carboxyl-C $(20.09 \%-22.78 \%)$, the phenolic-C accounted for only $5.50 \%-10.29 \%$ of the total organic C (Table 3). It would therefore appear that the carboxyl groups in JAS biochar play a dominant role in complexing $\mathrm{Cu}$. The observed decrease in the contents of both carboxyl and phenolic hydroxyl groups (Table 1) suggests that 

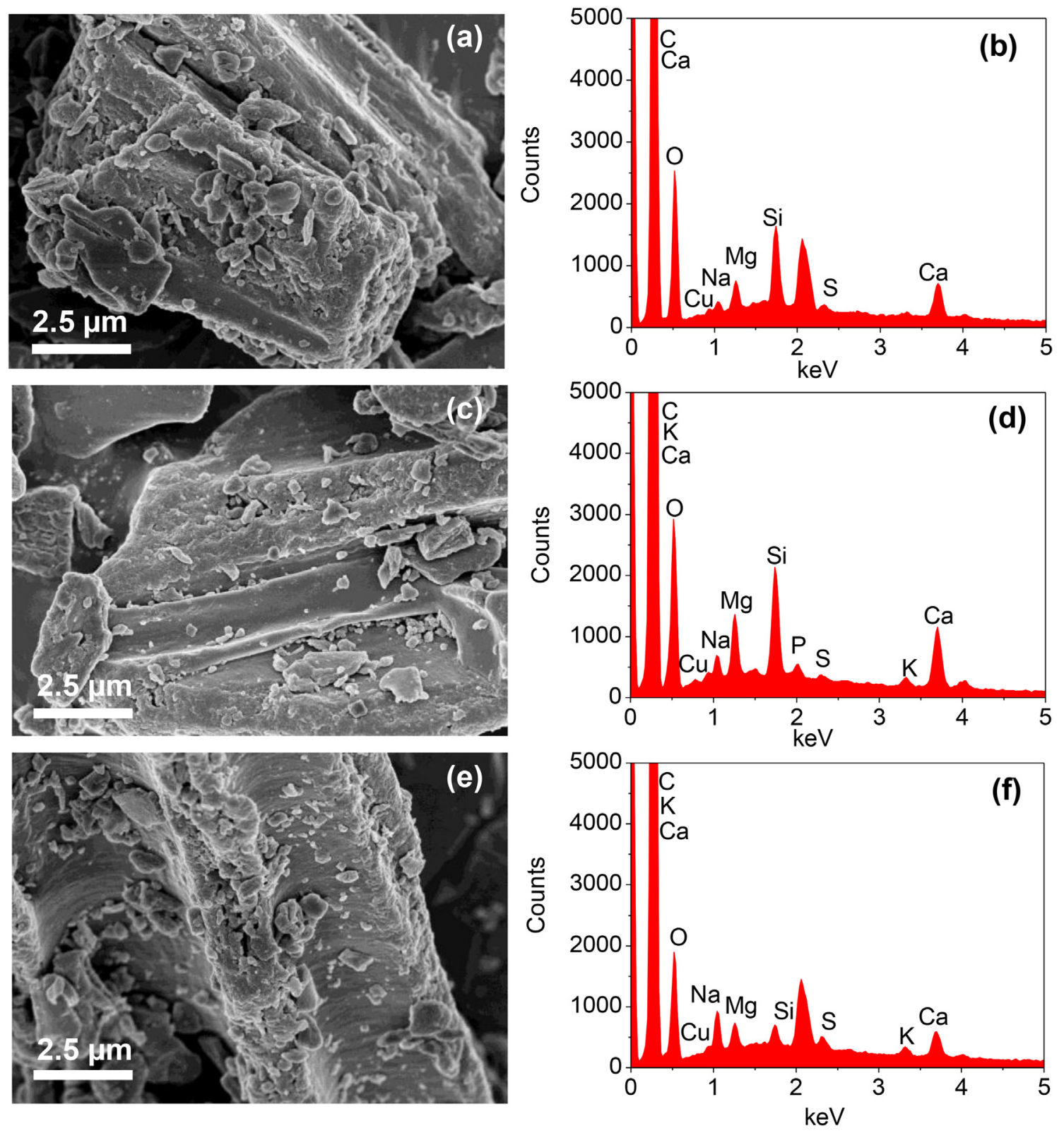

Fig. 6. Scanning electron micrographs and EDS spectra of Cu-loaded JAS biochars produced at 300 (a, b), 500 (c, d), and $700{ }^{\circ} \mathrm{C}(\mathrm{e}, \mathrm{f})$.

complexation declines in importance with a rise in pyrolysis temperature.

\subsubsection{Cu cation- $\pi$ bonding}

Cation- $\pi$ bonding between polyvalent cations and aromatic moieties in biochar (Gao et al., 2019; Wang et al., 2015) can be conceptualized as a non-covalent interaction of a positively charged ion with the planar surface of an aromatic $\pi$ electron donor system (Mecozzi et al., 1996). In black carbon, the common $\pi$ electron donors are polycondensed aromatic structures, the electrondonating ability of which becomes stronger as the number of associated rings increases (Keiluweit and Kleber, 2009).

The FTIR spectra of the JAS biochars showed peaks attributable to $\mathrm{C}-\mathrm{H}$ bending of aromatic compounds in furan and pyridine near 760,810 , and $860 \mathrm{~cm}^{-1}$ after loading with $\mathrm{Cu}$ (Fig. 1). These peaks shifted to a higher wavenumber with a rise in pyrolysis temperature, suggestive of $\mathrm{Cu}$ cation- $\pi$ bonding.
The C K-edge XANES spectra provide unique information on the electronic structures of aromatic moieties in the JAS-derived biochars. As already remarked on, high charring temperatures $\left(\geq 500^{\circ} \mathrm{C}\right.$ ) are conducive to aromatic-C formation. Indeed, extensive conjugated graphene-like aromatic structures were detectable in the JAS700 sample (Table 3, Fig. 2c). Furthermore, the C XANES spectra of all $\mathrm{Cu}$-loaded biochar samples showed a broadening of the total aromatic-C ( $1 \mathrm{~s}-\pi^{*}$ transitions) feature, extending toward 284 and $286 \mathrm{eV}$, with a lower-energy shoulder adjacent to the $1 \mathrm{~s}-\pi^{*}$ feature. These observations are strongly indicative of hybridization involving the $\pi$ cloud of aromatic rings and $\mathrm{Cu}$ d-orbitals (Schultz et al., 2013). The spectra of JAS500 and JAS700 showed a more pronounced broadening and splitting of the $1 \mathrm{~s}-\pi^{*}$ feature as compared with JAS300. This finding would suggest that $\mathrm{Cu}^{2+} / \mathrm{Cu}^{+}-$ $\pi$ bonding increases in strength with a rise in pyrolysis temperature. 


\subsubsection{Precipitation and other mechanisms}

SEM-EDS analysis of the samples after $\mathrm{Cu}$ sorption confirmed the co-existence of $\mathrm{Cu}$ with inorganic components in the JAS biochar (Fig. 6). Anions such as $\mathrm{OH}^{-}, \mathrm{CO}_{3}^{2-}, \mathrm{SO}_{4}^{2-}$, and $\mathrm{PO}_{4}^{3-}$, released from the biochar at an equilibrium $\mathrm{pH}$ of 5.58-5.71 (SI Fig. S1b), would combine with $\mathrm{Cu}^{2+} / \mathrm{Cu}^{+}$to yield a co-precipitate. Indeed, the $\mathrm{PO}_{4}^{3-}$ bending band near $610 \mathrm{~cm}^{-1}$ in the FTIR spectra of all three biochar samples broadened and intensified after reaction with $\mathrm{Cu}$. This observation suggests the involvement of $\mathrm{PO}_{4}^{3-}$ (dissolved or mineral-bound) in $\mathrm{Cu}$ precipitation. Moreover, the increase in biochar $\mathrm{pH}$ with rising pyrolysis temperature (Table 1 ) is conducive to $\mathrm{Cu}$ precipitation. The XRD patterns indicated the formation of langite $\left(\mathrm{Cu}_{4}\left(\mathrm{SO}_{4}\right)(\mathrm{OH})_{6} \cdot 2 \mathrm{H}_{2} \mathrm{O}\right)$ at the surface of biochar produced at $\geq 500{ }^{\circ} \mathrm{C}$. A Cu(II)-rich hot spot, observed in the STXM image of JAS700, is also indicative of surface Cu precipitation.

In addition to the above-mentioned processes, cation exchange between $\mathrm{Cu}$ and metal cations (i.e. $\mathrm{Ca}^{2+}, \mathrm{Mg}^{2+}$ ), associated with surface functional groups in biochar, may contribute to $\mathrm{Cu}$ sorption. Uchimiya et al. (2010) have suggested that in carbonaceous biochar, produced at high pyrolysis temperatures, cation exchange is less important than $\pi$ bonding and precipitation in immobilizing $\mathrm{Cu}(\mathrm{II})$. Because of the porous nature of biochar, physical sorption such as intraparticle diffusion may also come into play (Ding et al., 2014). In view of the small specific surface area of JAS biochar, however, intraparticle diffusion is probably not an important mechanism.

\section{Conclusions}

The molecular properties and $\mathrm{Cu}$ sorption capacity of biochar, derived from Jerusalem artichoke stalks, are closely related to the temperature of pyrolysis. Cu sorption is controlled by a variety of mechanisms, ranging from complexation through precipitation to $\mathrm{Cu}-\pi$ bonding. Physical sorption may also play a role, albeit a minor one, in $\mathrm{Cu}$ immobilization. As far as we know, this is the first attempt at using a suite of state-of-the-art analytical techniques to probe $\mathrm{Cu}$ sorption by biochar. The information gained from this investigation is valuable to developing methods for the remediation of heavy metal-contaminated soil and wastewater by halophyte-derived biochar.

\section{Acknowledgements}

This research was supported by the National Natural Science Foundation of China $(41501522,41571310)$, the Chinese National Key Research and Development Program (2016YFD0200303 and 2016YFE0106400), and the One Hundred Talents Program of Chinese Academy of Sciences (Y629041021). Anne Austin, Manaaki Whenua-Landcare Research, New Zealand, edited this manuscript.

\section{Appendix A. Supplementary data}

Supplementary data to this article can be found online at https://doi.org/10.1016/j.envpol.2019.04.128.

\section{References}

Ahmad, M., Rajapaksha, A.U., Lim, J.E., Zhang, M., Bolan, N., Mohan, D., Vithanage, M., Lee, S.S., Ok, Y.S., 2014. Biochar as a sorbent for contaminant management in soil and water: a review. Chemosphere 99, 19-33.

Armbruster, M.K., Schimmelpfennig, B., Plaschke, M., Rothe, J., Denecke, M.A Klenze, R., 2009. Metal-ion complexation effects in C 1s-NEXAFS spectra of carboxylic acids-evidence by quantum chemical calculations. J. Electron Spectrosc. 169 (1), 51-56.

Awad, Y.M., Ok, Y.S., Abrigata, J., Beiyuan, J., Beckers, F., Tsang, D.C.W., Rinklebe, J., 2018. Pine sawdust biomass and biochars at different pyrolysis temperatures change soil redox processes. Sci. Total Environ. 625, 147-154.

Beesley, L., Moreno-Jimenez, E., Gomez-Eyles, J.L., Harris, E., Robinson, B., Sizmur, T.
2011. A review of biochars' potential role in the remediation, revegetation and restoration of contaminated soils. Environ. Pollut. 159 (12), 3269-3282.

Bogusz, A., Oleszczuk, P., Dobrowolski, R., 2015. Application of laboratory prepared and commercially available biochars to adsorption of cadmium, copper and zinc ions from water. Bioresour. Technol. 196, 540-549.

Brandes, J.A., Cody, G.D., Rumble, D., Haberstroh, P., Wirick, S., Gelinas, Y., 2008 Carbon K-edge XANES spectromicroscopy of natural graphite. Carbon 46 (11), 1424-1434.

Cao, J.S., Wang, C., Fang, F., Lin, J.X., 2016. Removal of heavy metal Cu(II) in simulated aquaculture wastewater by modified palygorskite. Environ. Pollut. 219, 924-931.

Chi, Z.M., Zhang, T., Cao, T.S., Liu, X.Y., Cui, W., Zhao, C.H., 2011. Biotechnological potential of inulin for bioprocesses. Bioresour. Technol. 102 (6), 4295-4303.

Deacon, G.B., Phillips, R.J., 1980. Relationships between the carbon-oxygen stretching frequencies of carboxylato complexes and the type of carboxylate coordination. Coord. Chem. Rev. 33 (3), 227-250.

Ding, W.C., Dong, X.L., Ime, I.M., Gao, B., Ma, L.Q., 2014. Pyrolytic temperatures impact lead sorption mechanisms by bagasse biochars. Chemosphere 105, $68-74$.

Dong, X.L., Ma, L.Q., Li, Y.C., 2011. Characteristics and mechanisms of hexavalent chromium removal by biochar from sugar beet tailing. J. Hazard Mater. 190 (1-3), 909-915.

Gao, L.Y., Deng, J.H., Huang, G.F., Li, K., Cai, K.Z., Liu, Y., Huang, F., 2019. Relative distribution of $\mathrm{Cd}^{2+}$ adsorption mechanisms on biochars derived from rice straw and sewage sludge. Bioresour. Technol. 272, 114-122.

Godlewska, P., Schmidt, H.P., Ok, Y.S., Oleszczuk, P., 2017. Biochar for composting improvement and contaminants reduction. A review. Bioresour. Technol. 246, 193-202.

Hay, M.B., Myneni, S.C.B., 2007. Structural environments of carboxyl groups in natural organic molecules from terrestrial systems. Part 1: infrared spectroscopy. Geochem. Cosmochim. Acta 71 (14), 3518-3532.

Hitchcock, A.P., Wen, A.T., Ruhl, E., 1990. Inner-shell electron-energy loss spectroscopy of organometallic compounds. J. Electron Spectrosc. 51, 653-660.

Ho, Y.S., 2006. Review of second-order models for adsorption systems. J. Hazard Mater. 136 (3), 681-689.

Ho, Y.S., Huang, C.T., Huang, H.W., 2002. Equilibrium sorption isotherm for metal ions on tree fern. Process Biochem. 37 (12), 1421-1430.

International Humic Substances Society (IHSS), 2016. Acidic Functional Groups of IHSS Samples accessed in. http://www.humicsubstances.org/acidity.html. (Accessed July 2017).

Keiluweit, M. Kleber, M., 2009. Molecular-level interactions in soils and sediments: the role of aromatic pi-systems. Environ. Sci. Technol. 43 (10), 3421-3429.

Keiluweit, M., Nico, P.S., Johnson, M.G., Kleber, M., 2010. Molecular-level interactions in soils and sediments: the role of aromatic pi-systems. Environ. Sci. Technol. 44 (4), 1247-1253.

Klüpfel, L., Keiluweit, M., Kleber, M., Sander, M., 2014. Redox properties of plant biomass-derived black carbon (biochar). Environ. Sci. Technol. 48 (10), 5601-5611.

Li, H., Dong, X.L., Da Silva, E.B., De Oliveira, L.M., Chen, Y.S., Ma, L.Q., 2017. Mechanisms of metal sorption by biochars: biochar characteristics and modifications. Chemosphere 178, 466-478.

Li, M., Lou, Z.J., Wang, Y., Liu, Q., Zhang, Y.P., Zhou, J.Z., Qian, G.R., 2015. Alkali and alkaline earth metallic (AAEM) species leaching and $\mathrm{Cu}$ (II) sorption by biochar. Chemosphere 119, 778-785.

Li, S.Z., Chan-Halbrendt, C., 2009. Ethanol production in (the) People's Republic of China: potential and technologies. Appl. Energy 86, S162-S169.

Lin, Q., Xu, X., Chen, Q., Fang, J., Shen, X., Zhang, L., 2018. Changes in structural characteristics and metal speciation for biochar exposure in typic udic ferrisols. Environ. Sci. Pollut. Res. 25 (1), 153-162.

Luo, F., Song, J., Xia, W., Dong, M., Chen, M., Soudek, P., 2014. Characterization of contaminants and evaluation of the suitability for land application of maize and sludge biochars. Environ. Sci. Pollut. Res. 21 (14), 8707-8717.

Luo, L., Lv, J., Chen, Z., Huang, R., Zhang, S., 2017. Insights into the attenuated sorption of organic compounds on black carbon aged in soil. Environ. Pollut. 231, 1469-1476.

Mecozzi, S., West, A.P., Dougherty, D.A., 1996. Cation-pi interactions in aromatics of biological and medicinal interest: electrostatic potential surfaces as a useful qualitative guide. Proc. Natl. Acad. Sci. U.S.A. 93 (20), 10566-10571.

Park, J.H. Cho, J.S., Ok, Y.S. Kim, S.H. Kang S.W. Choi, IW. Heo, J.S., DeLaune, R.D. Seo, D.C., 2015. Competitive adsorption and selectivity sequence of heavy metals by chicken bone-derived biochar: batch and column experiment J. Environ. Sci. Health A Tox. Hazard. Subst. Environ. Eng. 50 (11), 1194-1204.

Prévoteau, A., Ronsse, F., Cid, I., Boeckx, P., Rabaey, K., 2016. The electron donating capacity of biochar is dramatically underestimated. Sci. Rep. 6 (1), 32870.

Qian, L., Chen, B., 2013. Dual role of biochars as adsorbents for aluminum: the effects of oxygen-containing organic components and the scattering of silicate particles. Environ. Sci. Technol. 47 (15), 8759-8768.

Rajapaksha, A.U., Chen, S.S., Tsang, D.C.W., Zhang, M., Vithanage, M., Mandal, S., Gao, B., Bolan, N.S., Ok, Y.S., 2016. Engineered/designer biochar for contaminant removal/immobilization from soil and water: potential and implication of biochar modification. Chemosphere 148, 276-291.

Saijo, Y., Kinoshita, N., Ishiyama, K., Hata, S., Kyozuka, J., Hayakawa, T., Nakamura, T., Shimamoto, K., Yamaya, T., Izui, K., 2001. A Ca ${ }^{2+}$-dependent protein kinase that endows rice plants with cold- and salt-stress tolerance functions in vascular bundles. Plant Cell Physiol. 42 (11), 1228-1233. 
Schultz, B.J., Jaye, C., Lysaght, P.S., Fischer, D.A., Prendergast, D., Banerjee, S., 2013. On chemical bonding and electronic structure of graphene-metal contacts. Chem. Sci. 4 (1), 494-502.

Sedlmair, J., Gleber, S.C., Peth, C., Mann, K., Niemeyer, J., Thieme, J., 2012. Characterization of refractory organic substances by NEXAFS using a compact X-ray source. J. Soils Sediments 12 (1), 24-34.

Shen, Y.S., Wang, S.L., Tzou, Y.M., Yan, Y.Y., Kuan, W.H., 2012. Removal of hexavalent $\mathrm{Cr}$ by coconut coir and derived chars-the effect of surface functionality. Bioresour. Technol. 104, 165-172.

Singh, B., Fang, Y.Y., Cowie, B.C.C., Thomsen, L., 2014. NEXAFS and XPS characterisation of carbon functional groups of fresh and aged biochars. Org. Geochem. 77, 1-10.

Solomon, D., Lehmann, J., Wang, J., Kinyangi, J., Heymann, K., Lu, Y.S., Wirick, S. Jacobsen, C., 2012. Micro- and nano-environments of C sequestration in soil: a multi-elemental STXM-NEXAFS assessment of black C and organomineral associations. Sci. Total Environ. 438, 372-388.

Sowers, T.D., Adhikari, D., Wang, J., Yang, Y., Sparks, D.L., 2018. Spatial associations and chemical composition of organic carbon sequestered in $\mathrm{Fe}, \mathrm{Ca}$, and organic carbon ternary systems. Environ. Sci. Technol. 52 (12), 6936-6944.

Sumaraj, Padhye, L.P., 2017. Influence of surface chemistry of carbon materials on their interactions with inorganic nitrogen contaminants in soil and water Chemosphere 184, 532-547.

Tan, X.F., Liu, Y.G., Zeng, G.M., Wang, X., Hu, X.J., Gu, Y.L., Yang, Z.Z., 2015. Application of biochar for the removal of pollutants from aqueous solutions. Chemosphere 125, 70-85.

Thyrel, M., Backman, R., Thanell, K., Karunakaran, C., Skyllberg, U., Lestander, T.A. 2016. Nanomapping and speciation of $\mathrm{C}$ and $\mathrm{Ca}$ in thermally treated lignocellulosic cell walls using scanning transmission X-ray microscopy and K-edge XANES. Fuel 167, 149-157.

Tu, C., Liu, Y., Wei, J., Li, L.Z., Scheckel, K.G., Luo, Y.M., 2018. Characterization and mechanism of copper biosorption by a highly copper-resistant fungal strain isolated from copper-polluted acidic orchard soil. Environ. Sci. Pollut. Res. 25
(25), 24965-24974.

Uchimiya, M., Lima, I.M., Thomas Klasson, K., Chang S., Wartelle, L.H., Rodgers, J.E. 2010. Immobilization of heavy metal ions $\left(\mathrm{Cu}^{\mathrm{II}}, \mathrm{Cd}^{\mathrm{II}}, \mathrm{Ni}^{\mathrm{II}}\right.$, and $\left.\mathrm{Pb}^{\mathrm{II}}\right)$ by broiler litter-derived biochars in water and soil. J. Agric. Food Chem. 58, 5538-5544.

Uchimiya, M., Wartelle, L.H., Klasson, K.T., Fortier, C.A., Lima, I.M., 2011. Influence of pyrolysis temperature on biochar property and function as a heavy metal sorbent in soil. J. Agric. Food Chem. 59 (6), 2501-2510.

Wang, Z.Y., Liu, G.C., Zheng, H., Li, F.M., Ngo, H.H., Guo, W.S., Liu, C., Chen, L., Xing, B.S., 2015. Investigating the mechanisms of biochar's removal of lead from solution. Bioresour. Technol. 177, 308-317.

Wei, J., Tu, C., Yuan, G.D., Bi, D.X., Xiao, L., Theng, B.K.G., Wang, H.L., Ok, Y.S., 2019. Carbon-coated montmorillonite nanocomposite for the removal of chromium(VI) from aqueous solutions. J. Hazard Mater. 368, 541-549.

Wei, J., Tu, C., Yuan, G.D., Bi, D.X., Wang, H.L., Zhang, L.J., Theng, B.K.G., 2018. Pyrolysis temperature-dependent changes in the characteristics of biochar-borne dissolved organic matter and its copper binding properties. Bull. Environ. Contam. Toxicol. https://doi.org/10.1007/s00128-018-2392-7.

Xu, X.Y., Zhao, Y.H., Sima, J., Zhao, L., Masek, O., Cao, X.D., 2017. Indispensable role of biochar-inherent mineral constituents in its environmental applications: a review. Bioresour. Technol. 241, 887-899.

Xu, X.Y., Huang, H., Zhang, Y., Xu, Z.B., Cao, X.D., 2019. Biochar as both electron donor and electron shuttle for the reduction transformation of $\mathrm{Cr}(\mathrm{VI})$ during its sorption. Environ. Pollut. 244, 423-430.

Yang, H.P., Yan, R., Chen, H.P., Lee, D.H., Zheng, C.G., 2007. Characteristics of hemicellulose, cellulose and lignin pyrolysis. Fuel 86 (12-13), 1781-1788.

Yuan, Y., Bolan, N., Prévoteau, A., Vithanage, M., Biswas, J.K., Ok, Y.S., Wang, H.L. 2017. Applications of biochar in redox-mediated reactions. Bioresour. Technol. 246, 271-281.

Zhang, J.S., Stanforth, R., 2005. Slow adsorption reaction between arsenic species and goethite (alpha-FeOOH): diffusion or heterogeneous surface reaction control. Langmuir 21 (7), 2895-2901. 